\title{
NOTES ON SOME AFROTROPICAL CRAMBINAE (LEPIDOPTERA PYRALOIDEA), CHIEFLY COLLECTED IN THE IVINDO NATIONAL PARK IN GABON, WITH DESCRIPTIONS OF NEW SPECIES
}

\author{
a Corresponding member, Muséum d'historie naturelle de Genève, Swtzerland; via Sant'Agostino, 51 - I-10051, Avigliana \\ (Torino), Italy. \\ Corresponding Author: Graziano Bassi; alphacrambus@gmail.com \\ Bassi G. - Notes on some Afrotropical Crambinae (Lepidoptera Pyraloidea), chiefly collected in the Ivindo National Park \\ in Gabon, with descriptions of new species. \\ The results of multi-year studies on undetermined specimens integrated with those of a research expedition in the \\ Ivindo forest in Gabon are given. Three new species are described and illustrated: Chrysocatharylla larseni sp. n., \\ Calamotropha hausmanni sp. n. and Calamotropha paradiakonoffi sp. n.; the new synonymy Pseudocatharylla ruwen- \\ zorella Błeszyński = Pseudocatharylla tisiphone Bassi syn. n. is established; seven species are reported as new to Gabon .
}

KEY Words: Cameroon, Crambidae, distribution, Gabon, Kenya, new synonymy, Uganda.

\section{INTRODUCTION}

Crambinae are found the world over and comprise 2047 described species, of which 436 are represented in the Afrotropical region (Nuss et al., August 2018). The Gabonese fauna is among the more poorly known, with only two species cited for the country: Calamotropha subdiodonta Błeszyński and Culladia troglodytella (Snellen) (De Prins \& De Prins, August 2018).

This work is based on the specimens collected during 10 days of field work at the Ipassa Research Station (Ivindo National Park, Ogooué-Ivindo Province) in Gabon, integrated with the data recorded from the material studied in the last decades.

The present material is rich enough to permit the description of three new species, establish a new synonymy and to extend the documented geographic distribution of some previously described species.

\section{MATERIAL AND METHODS}

Genitalia preparations were made following RoBINSON (1976). The terminology of the genitalia follows KLOTS (1970) and KRISTENSEN (2003). Genitalia photographs were taken with a Canon S120 digital camera. The habitus photos were made with a Nikon D300 digital camera. The images were enhanced with Adobe Photoshop Elements. DNA sequencing was performed at the Canadian Centre for DNA Barcoding following standard high-throughput protocols (IVANOVA et al., 2006; DEWAARD et al., 2008). The length of the labial palpus is compared to the maximum diameter of the composite eye in side view. The distribution data are taken, if not otherwise stated, from the material personally studied and from Afromoths database (De Prins \& De Prins, accessed August 2018). The endings of specific epithets have been changed, where applicable, in accordance with the International Code of Zoological Nomenclature, chap. 7, art. 34.2.
Abbreviations used:

BC ZSM = Bar Code Zoologische Staatssammlung München.

BMNH $=$ Natural History Museum, London, UK (formerly British Museum (Natural History).

$\mathrm{HNHM}=$ Hungarian Natural History Museum, Budapest.

$\mathrm{MHNG}=$ Muséum d'histoire naturelle, Genève.

$\mathrm{RMCA}=$ Royal Museum of Central Africa, Tervuren.

$\mathrm{CGB}=$ Bassi personal collection, Avigliana (Torino).

$\mathrm{GS} . . . \mathrm{BM}=$ Genitalia slide.... British Museum.

GS...GB $=$ Genitalia slide.... G. Bassi.

ZSM = Zoologische Staatssammlung München

\section{TAXONOMY}

Chrysocatharylla larseni $\mathrm{sp} . \mathrm{n}$.

Holotype male: Gabon, Ivindo-Ogooué Prov[ince], Ipassa-Makokou Res[earch] St[ation], 500m, 1424.III.2015, $00^{\circ} 31^{\prime} \mathrm{N} 12^{\circ} 48^{\prime} \mathrm{E}$, lux, G. Bassi legit, GS 5882 GB, BC ZSM 92316, 49010 CGB.

Paratype male: Nigeria, Benin City, Sapoba Forest Reserve, 10-13.III.1972, E. W. Classey [legit], BM 1972190, GS 2373 GB, BMNH.

Etymology - The species is dedicated to Dr Knud Larsen, well-known Danish specialist of Tortricidae, to thank him for his amicable donation of the holotype specimen, caught in one of his light-traps.

Diagnosis $-C$. larseni $\mathrm{sp}$. n. is well distinguished from others congeners in the wing coloration (Fig. I, 1), especially for the two well-defined fasciae in the forewings. The male genitalia (Fig. II, 5) are most similar to those of C. oenescentella (Hampson) (see BASSI, 1999: figs 3, 4) in the structure of the phallus and cornutus, but the valva without processes is diagnostic. The cup-shaped scent organ (Fig. II, 6) distinguish C. larseni from any other known Afrotropical Crambinae. 


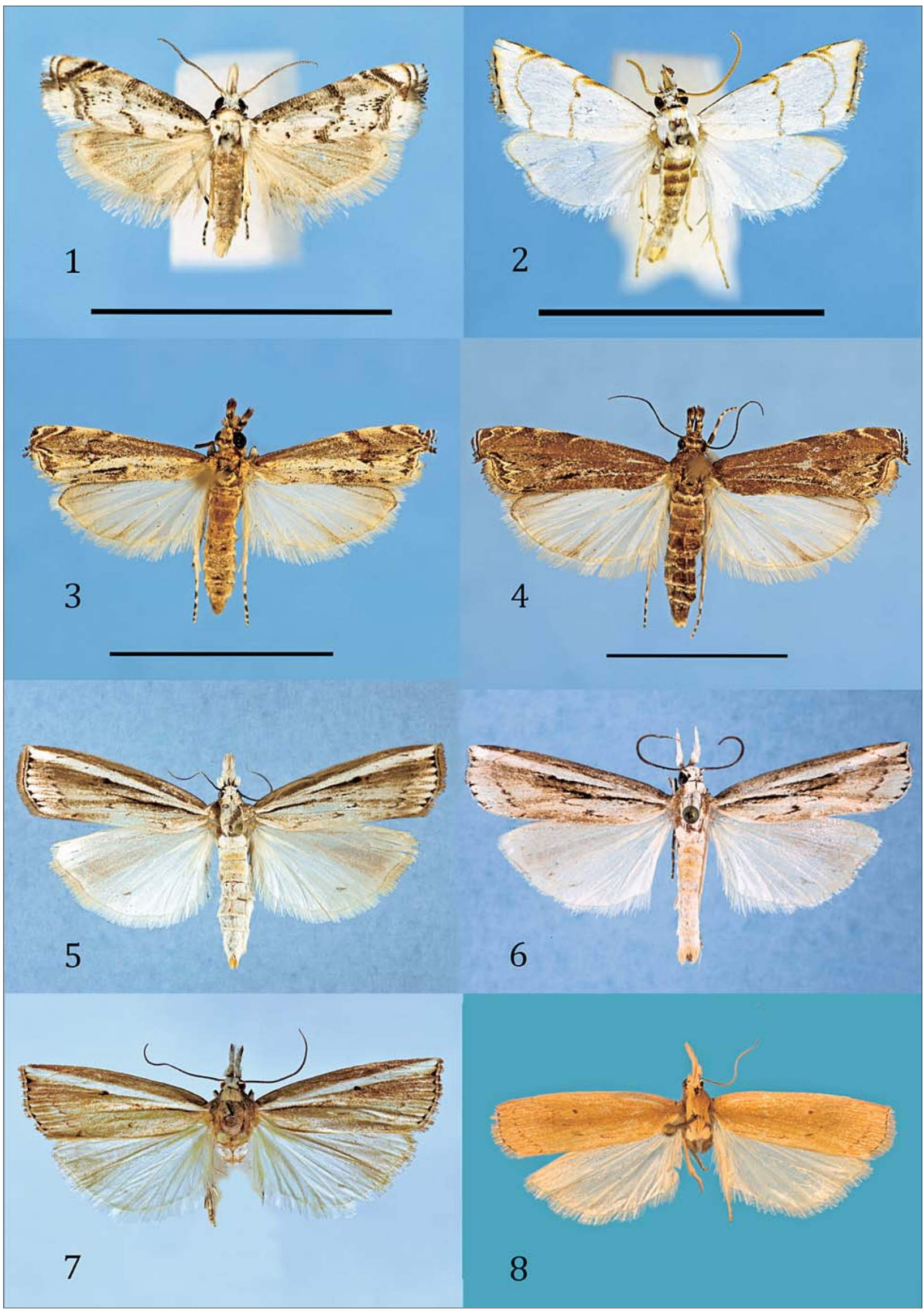

Fig. I - Crambinae spp. habiti. Scale bars $=10 \mathrm{~mm}$. (1) Chrysocatharylla larseni $\mathrm{sp}$. n., holotype (2) Pseudocatharylla argenticilia (Hampson), male, Gabon (3) Mesolia microdontalis (Hampson), male, Gabon (4) Mesolia microdontalis (Hampson), female, Gabon (5) Calamotropha hausmanni sp. n., female paratype, wingspan $36 \mathrm{~mm}$ (6) Calamotropha hausmanni sp. n., holotype (7) Calamotropha athena Błeszyński, female, Cameroon, wingspan $27 \mathrm{~mm}$ (8) Calamotropha paradiakonoffi sp. n., holotype. 

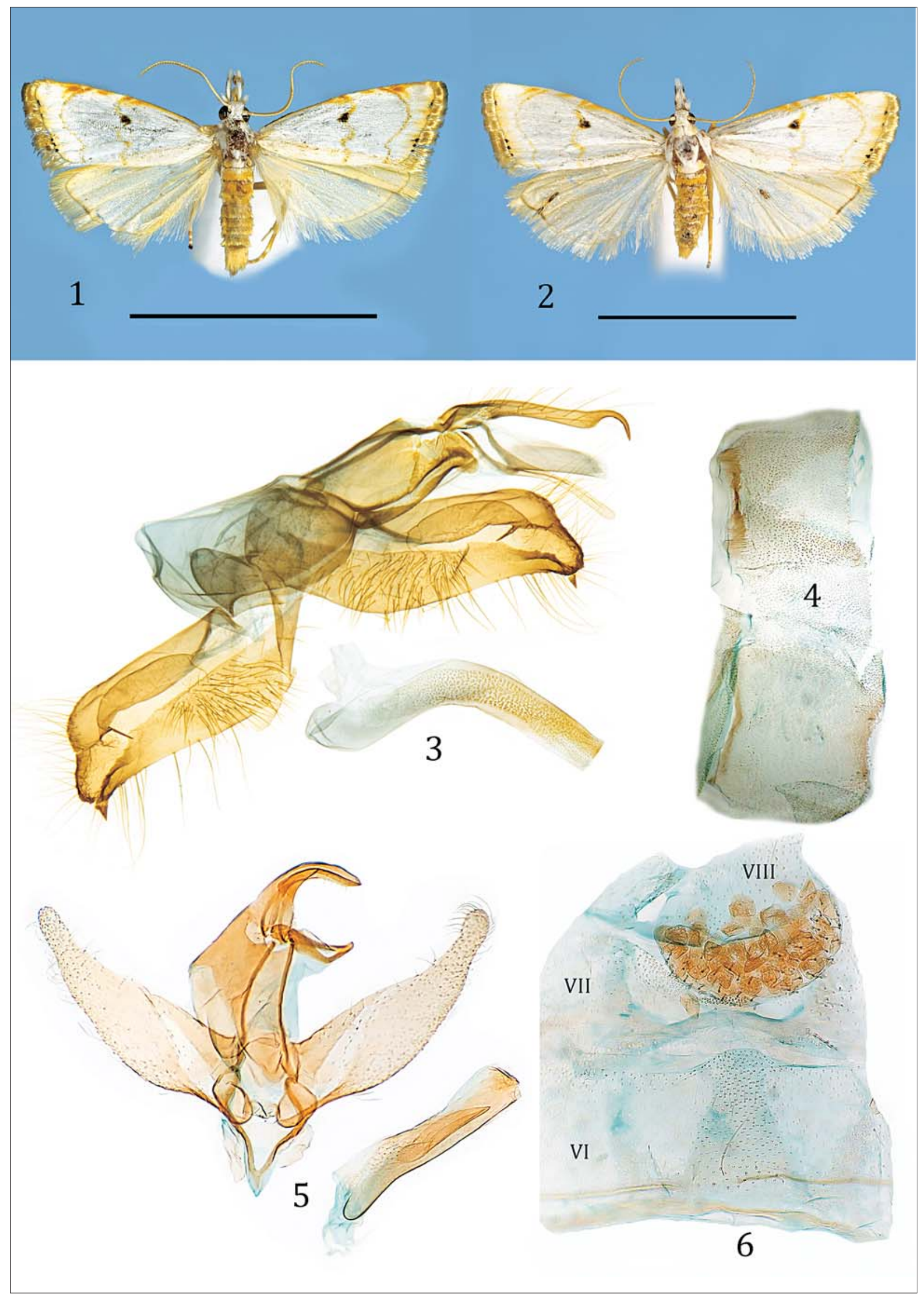

Fig. II - Crambinae spp. habiti and male genitalia. Scale bars $=10 \mathrm{~mm}$., genitalia not to scale. (1) Pseudocatharylla ruwenzorella Błeszyński, male, Gabon (2) Pseudocatharylla ruwenzorella Błeszyński, female, Gabon (3) Calamotropha hausmanni sp. n., paratype, male genitalia (4) Calamotropha hausmanni sp. n., same paratype, eighth abdominal segment sclerotizations (5) Chrysocatharylla larseni sp. n., holotype, male genitalia (6) Chrysocatharylla larseni sp. n., holotype, abdominal structure, segments specified. 
COI barcode sequence of the holotype (658 bp):

AACTTTATATTTTATCTTTGGAATTTGAGCAGGAA TAGTAGGTACATCATTAAGTCTTCTAATTCGAGCTG AATTAGGAAACCCTGGCTCACTAATTGGGGATGAT CAAATTTACAATACTATTGTAACAGCTCATGCATTTA TTATAATTTTTTTCATAGTAATACCAATTATAATTGGA GGATTTGGAAATTGATTAGTACCTTTAATATTAGGA GCCCCCGATATAGCATTCCCCCGAATAAATAATATAA GATTTTGACTATTGCCCCCCTCTTTAACCTTATTAAT TTCCAGCAGAATTGTTGAAAATGGGGCAGGTACAG GATGAACAGTGTATCCCCCCCTTTCATCTAATATCG CTCACGGAGGCAGTTCTGTTGATCTAGCTATTTTTT CATTACATTTAGCTGGTATTTCTTCTATTTTAGGAGC TATTAATTTTATTACCACTATTATTAACATACGAATTA ATAGATTATCATTTGATCAAATACCTTTATTTGTATGA TCAGTGGGAATTACTGCCTTACTCCTTCTTCTCTCAT TACCTGTATTGGCAGGAGCTATTACTATATTATTAAC AGATCGAAACTTAAATACATCTTTTTTTGACCCTGCT GGAGGGGGAGATCCTATTCTTTACCAACATTTATTT.

DESCRIPTION (Fig. I, 1) - Wingspan: holotype $12 \mathrm{~mm}$, paratype $11 \mathrm{~mm}$. Labial palpi $3.5 \times$ longer than widest diameter of eye, white on inner side, brown on lower outer side, white on upper outer side. Maxillary palpi white. Antennae thickened basally, slightly serrate distally, grey with silvery grey costa. Frons rounded, produced, white sprinkled with grey. Ocelli absent. Chaetosemata minute. Head white. Patagia basally grey, then silvery white. Tegulae white suffused with yellow, with scattered silvery grey scales. Thorax white suffused with yellow, sprinkled with few silvery grey scales. Forewing ground colour white with yellow apical suffusion and sprinkled with black scales; costa grey; antemedial fascia grey, bowed in medially; postmedial fascia silvery white, angled at R5-M1, bordered grey brown from angle to costa and silvery grey from angle to dorsum; terminal line brown grey around termen, then white; two small terminal dots medially and subdorsally; fringes silvery white, with short scales bordered grey brown at termen, and a medial silvery grey dot; underside strongly suffused with black. Hindwings grey suffused with yellow; fringes concolorous; underside yellowish white with costa suffused with black. Forelegs black; mid- and hindlegs yellowish white with tarsi annulated black and white; first pair of spurs longer than second pair. Abdomen grey with yellow suffusion on first segments; anal tuft white with light yellow suffusion; eight sternite modified into cup-shaped (Fig. II, 6) structure spiny on inner side and apparently full of a liquid that solidified during the boiling process; sixth and seventh abdominal sternites modified to support the eighth.

Male genitalia (Fig. II, 5): Uncus and gnathos of equal lengths, both curved and apically pointed; tegumen subtriangular; juxta shield-shaped, lightly sclerotized; vinculum triangular; valva without processes, slendering toward rounded cucullus; phallus as long as valva, with small phallobase; vesica with one large and elongated cornutus and some scobinations.

Female unknown.

REMARKS - The general aspect of the moths and some characteristics of the genitalia, i.e. the simple valva and the phallus features, justify the placement of larseni in Chrysocatharylla Bassi, even if the presence of a peculiar abdominal structure (probably a scent organ) could inspire its placement in a new genus. The holotype is barcoded, but the lack of a female and the paucity of available barcoded specimens of Chrysocatharylla and allied genera for a relevant DNA comparison suggest to defer an eventual generic description.

\section{Pseudocatharylla argenticilia (Hampson, 1919) \\ Crambus argenticilia Hampson, 1919a: 439. Type locality: Sierra Leone.}

Material EXAMINed - a male and 2 females, Gabon, Ivindo-Ogooué Prov[ince], Ipassa-Makokou Res[earch] St[ation], 500m, 14-24.III.2015, 00³1'N 12 ${ }^{\circ} 48^{\prime} \mathrm{E}$, lux, G. Bassi legit, CG 5759 and 5765 GB, CGB.

REMARKS - The species (Fig. I, 2) is known from Cameroon, Central African Republic, Gabon (new record), Ghana, Guinea, Nigeria, and Sierra Leone.

Pseudocatharylla ruwenzorella Błeszyński, 1964 Type locality: Uganda.

Pseudocatharylla tisiphone Bassi, 1999:167, 168. Type locality: Cameroon. syn. n.

MATERIAL EXAMINED - 3 males, 2 females, Gabon, IvindoOgooué Prov[ince], Ipassa-Makokou Res[earch] St[ation], 500m, 14-24.III.2015, 00³1'N 1248'E, lux, G. Bassi legit, BC ZSM 92299 and 92300, GS 5718 and 5722, CGB.

REMARKS - Species known from the Republic of the Congo (new record: CGB), Democratic Republic of the Congo (new record: $M H N G$ ), Cameroon (new record: CGB), Gabon (new record), Uganda. The examination of the Gabonese specimens of both sexes, both through genitalia and DNA analysis, allows their correct match and to establish the synonymy of $P$. ruwenzorella with the holotype of $P$. tisiphone Bassi. Females (Fig. II, 2) are paler and slightly larger than males (Fig. II, 1). COI barcode sequence of specimen ZSM 92299 (658 bp):

AACTTTATATTTTATTTTTGGTATTTGAGCTGGAATA GTAGGAACATCATTAAGATTATTAATTCGAGCTGAA TTGGGAAACCCTGGATCTTTAATTGGAGATGATCAA ATTTATAATACTATTGTTACAGCTCATGCATTTATTAT AATTTTTTTTATAGTTATACCCATTATAATTGGAGGAT TTGGAAACTGATTAGTTCCCCTAATACTAGGAGCTC CGGATATGGCATTCCCGCGAATAAATAATATAAGATT TTGATTATTACCTCCATCTTTAACCTTACTAATTTCA AGAAGAATTGTAGAAAATGGAGCTGGAACAGGTT GAACAGTTTACCCCCCCCTTTCATCAAATATTGCTC ATGGGGGAAGATCAGTTGACCTTGCAATTTTTTCCT TACATTTAGCTGGTATTTCATCTATTTTAGGAGCAAT TAATTTTATCACAACAATTATTAATATACGAATTAAT GAATTAACTTTTGATCAAATACCCCTATTTGTCTGAT CCGTGGGTATTACAGCTTTATTACTTCTTCTTTCCCT ACCTGTATTAGCTGGAGCTATCACCATATTATTAACA GATCGAAACTTAAATACTTCTTTTTTTGACCCTGCT GGAGGGGGGGATCCAATTTTATACCAACATTTATTT.

Culladia achroella (Mabille, 1900)

Crambidion achroellum Mabille, 1900: 748. Type locality: Madagascar.

Material eXAmined - 4 females, Gabon, Ivindo-Ogooué Prov[ince], Ipassa-Makokou Res[earch] St[ation], 500m, 1424.III.2015, $00^{\circ} 31^{\prime} \mathrm{N} 12^{\circ} 48^{\prime} \mathrm{E}$, lux, G. Bassi legit, CGB.

REMARKS - Species known from Botswana, Democratic 
Republic of the Congo, Egypt, Ethiopia, Gabon (new record), Gambia, Kenya, Madagascar, Mauritius, Mozambique, Namibia, Nigeria, Réunion, Sao Tomé and Principe (new record: CGB), Saudi Arabia, Seychelles, South Africa, Sudan, Somalia, Tanzania, Yemen, Zimbabwe.

Culladia inconspicuella (Snellen, 1872) Crambus inconspicuellus Snellen, 1872: 102, 103. Type locality: Lower Guinea.

Material eXAmined - a male, Gabon, Ivindo-Ogooué Prov[ince], Ipassa-Makokou Res[earch] St[ation], 500m, 1424.III.2015, $00^{\circ} 31^{\prime} \mathrm{N} 12^{\circ} 48^{\prime} \mathrm{E}$, lux, G. Bassi legit, GS 5716 GB, CGB.

REMARKS - Species known from Cameroon (new record: CGB), Democratic Republic of the Congo, Ethiopia (BŁesZYŃsKi, 1970), Gabon (new record), Ivory Coast (BŁESZYŃSKI, 1970), Malawi (new record: CGB), Kenya (BŁESZYŃSKI, 1970), Mautitius, Réunion, Seychelles, Sierra Leone (BŁESZYŃsKI, 1970), South Africa.

Culladia troglodytella (Snellen, 1872) Crambus troglodytellus Snellen, 1872: 103, 104. Type locality: Lower Guinea.

Material EXAMINED - 2 males, Gabon, Ivindo-Ogooué Prov[ince], Ipassa-Makokou Res[earch] St[ation], 500m, 1424.III.2015, $00^{\circ} 31^{\prime} \mathrm{N} 12^{\circ} 48^{\prime} \mathrm{E}$, lux, G. Bassi legit, BC ZSM 92338, GS 5723 GB, CGB.

REMARKS - Species known from Cameroon (new record: CGB), Gabon, Ghana (new record: HNHM) Ivory Coast, Mauritius, Nigeria, Réunion. Data from Mauritius and Réunion seem doubtful and probably refer to C. achroella (Mabille) or C. inconspicuella (Snellen).

\section{Mesolia microdontalis (Hampson, 1919)}

Prionopteryx [sic] microdontalis Hampson, 1919b: 66, 67.

Material examined - A male and a female, Gabon, Ivindo-Ogooué Prov[ince], Ipassa-Makokou Res[earch] St[ation], 500m, 14-24.III.2015, 00³1'N 1248’E, lux, G. Bassi legit.

REMARKS - Described from 3 males and 6 females from Nigeria, "Gold Coast" and Sierra Leone. Even if in the BMNH there is a male labelled "Type, Gold Coast, G.C. Dudgeon, 1907-332, Prionapteryx microdontalis Type male Hmpsn, GS 7530 BM", the original description does not mention the word "type". M. microdontalis, like M. meyi Bassi (2013: figs. 3, 4) shows sexual dimorphism, with males (Fig. I, 3) paler and smaller than females (Fig. I, 4). Species known from Cameroon (new record: CGB, MHNG), Gabon (new record), The Gambia (new record: ZSM), Ghana, Nigeria, Sierra Leone.

\section{Calamotropha athena Błeszyński, 1961}

Type locality: Nigeria.

Material EXAMINED - A female, Gabon, Ogooué-Ivindo Province, Ipassa-Makokou Res[earch] St[ation], 500m, 1424.III.2015, 0031N 1248'E, lux, G. Bassi legit, GS 5770 GB, BC ZSM 92318, CGB.
REDESCRIPTION OF THE FEMALE GENITALIA (Fig. III, 2) Papillae anales elongated, moderately up-curved dorsally and slightly down curved ventrally. Apophyses posteriores $1.9 \mathrm{X}$ longer than apophyses anteriores, narrow and bulged basally. Apophyses anteriores sub-triangular, slightly curved inwards apically. Abdominal segment VIII large, strongly developed, sclerotized, bulged dorsally and also slightly bulged ventrally, joined to sterigma by sclerotized bridge. Ostium bursae sub-oval, with sterigma tubular, slightly bent outward, strongly produced for almost all of length of abdominal segment VIII, moderately enlarging apically. Ductus bursae twice as long as sterigma, moderately sclerotized basally, then wrinkled and distally scobinate. Ductus seminalis branching off at anterior onethird of ductus bursae. Corpus bursae suboval, shorter than ductus bursae, completely scobinate.

REMARKS - Described from a male holotype from Old Calabar [Nigeria], and two female paratypes from Sierra Leone and Masindi [Uganda], this species seems broadly distributed in Central and Western Africa. I know it from the Democratic Republic of the Congo (new record: RMCA), Cameroon (new record: CGB), Liberia (new record: Coll. Poltavsky, Rostov-on-Don, Russia). A redescription of the female genitalia was warranted because of the unclear illustration in the original description and for a better comparison with the new species described below.

\section{Calamotropha hausmanni sp. n.}

Holotype male: Kenya, 1600-1700 m, Nandi Prov[ince], Kakamega-Regenwald [Kakamega Forest National Reserve], Umg[ebung] [surroundings] Rondo, 5-10.V.1997, Eitschberger, Bauer \& Traub leg[unt], ex coll. EMEM, ZSM.

Paratypes: a male and two females, same data as holotype, GS 5035 and 5042 GB, ZSM and CGB.

Etymology - The species is dedicated to Dr Axel Hausmann, Head of the Lepidoptera Section in the ZSM, to thank him for his more than twenty-year friendship and for his great help during my visits to his Museum.

DiAGNOSIS - In wing pattern C. hausmanni (Figs I, 5 and 6) resembles $C$. athena Błeszyński (Fig. I, 7). However, $C$. hausmanni is larger and with more contrasted colours. The male genitalia of C. hausmanni (Fig. II, 3) are easily distinguishable by the strongly hooked uncus and two teeth on the valva . The female genitalia of C. hausmanni (Figs III, 1 and 3 ) can be distinguished from those of $C$. athena (Fig. III, 2) by the almost straight eighth abdominal tergite, the shorter apophyses posteriores and the sterigma almost straight as opposed to the arched and apically enlarged sterigma in $C$. athena. The other Afrotropical congeners with a strongly produced sterigma are $C$. diakonoffi Błeszyński (Figs III, 5 and 7 ) and $C$. paradiakonoffi sp. n. described below (Figs III, 4 and 6): both have longer apophyses anteriores and the sterigma is enlarging towards apex and wrinkled.

DESCRIPTION (Figs I, 5 and 6) - Wingspan: holotype 27 $\mathrm{mm}$, male paratype $21 \mathrm{~mm}$, female paratypes 32 and 36 $\mathrm{mm}$. Labial palpi $4 \times$ longer than widest diameter of eye, brown with upper and inner sides white. Maxillary palpi subtriangular, white with brown base. Antenna: in male thickened basally, slightly serrate distally, brown with silvery brown costa; in female thickened, brown to dark 


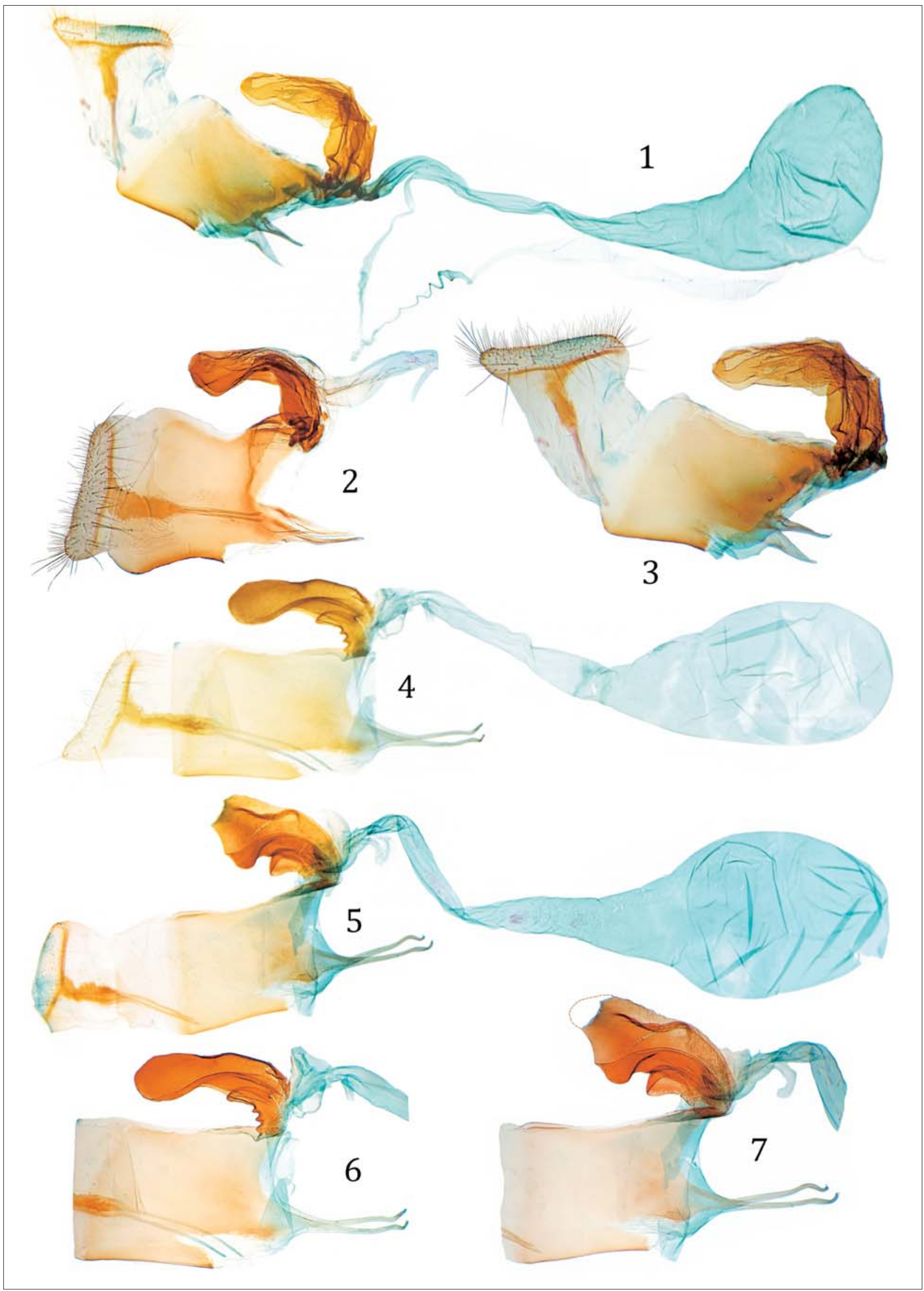

Fig. III - Crambinae spp. female genitalia. Not to scale. (1) Calamotropha hausmanni sp. n., paratype (2) Calamotropha athena Błeszyński, lateral view of distal part and sterigma - antrum complex, Cameroon (3) Calamotropha hausmanni sp. n., paratype, lateral view of distal part and sterigma - antrum complex (4) Calamotropha paradiakonoffi sp. n., holotype (5) Calamotropha diakonoffi Błeszyński, South Africa, Kwa-Zulu Natal (6) Calamotropha paradiakonoffi sp. n., lateral view of eighth abdominal segment and sterigma - antrum complex (7) Calamotropha diakonoffi Błeszyński, lateral view of eighth abdominal segment and sterigma - antrum complex. 
brown. Frons rounded, slightly produced, white. Ocelli and chaetosemata strongly reduced. Head white. Patagia white in middle, brown laterally. Tegulae brown, distally creamy brown. Thorax white with thin medial line brown. Forewing ground colour white and brown with welldeveloped medial dot; medial fascia ill-defined, wrinkled, running along dorsum up to the cell, without reaching costa; postmedial fascia strongly dentate, thin and widely outcurved at R5-M1; with eight subtriangular terminal dots; medial stripe white, ending at termen, basally bordered brown up to cell; apex moderately pointed; termen sinuous; fringes brown, with medial line darker; underside brown with distal costa, apex and termen golden yellow. Hindwings glossy white lightly suffused with yellow and brown; fringes ivory yellow dorsally, white ventrally; underside white with dorsal half strongly suffused with brown. Legs brown with welldeveloped tibial spurs. Abdomen with tergites white suffused with yellow; sternites yellow with two brown stripes laterally; anal tuft ivory yellow, darker in female. Sclerotizations of eight abdominal segment in male as in Fig. II, 4.

Male genitalia (Fig. II, 3): Uncus slightly longer and more sclerotized than gnathos, with long setae, apically strongly hooked, with pointed tip. Gnathos slender, slightly curved, with rounded tip. Tegumen subrectangular, more strongly sclerotized ventrally, with large membranous window at junction of uncus with gnathos. Vinculum stout, moderately bifid dorsally. Juxta membranous. Pseudosaccus subconical, large, 0.6 as long as vinculum. Valva subrectangular, 1.5 longer than vinculum, slightly curved distally; costa with rounded tip bearing long setae; sacculus longer than costa, tapering in a strongly sclerotized apical tooth; ventral fold sclerotized apically and covered with strong medium sized setae in basal half; costal fold bulged medially; distal end of bulge with slender and pointed tooth. Phallus large, gently curved, with several rough scobinations.

Female genitalia (Figs III, 1 and 3): Papillae anales elongated, slightly up-curved dorsally and slightly down curved ventrally. Apophyses posteriores 2.15 longer than apophyses anteriores, bulged basally, then narrowing. Apophyses anteriores sub-triangular. Abdominal segment VIII strongly developed, slightly oblique in side view, joined to sterigma by strongly sclerotized and spiny bridge. Ostium bursae suboval, spiny, with sterigma tubular, strongly produced to 0.75 length of abdominal segment VIII. Ductus bursae two times longer than corpus bursae, moderately sclerotized basally, then wrinkled and distally scobinate. Ductus seminalis branching off anteriorly at one-third of ductus bursae. Corpus bursae suboval and completely scobinate.

Calamotropha paradiakonoffi $\mathrm{sp} . \mathrm{n}$.

Holotype female: [Uganda] Kampala, 8.VI.[19]25, B:[?, unknown collector], Coll. Audéoud, GS 2592 GB, MHNG.

ETYMology - The name of the new species refers to its similarity to $C$. diakonoffi Błeszyński in female genitalia.

Diagnosis - A large Calamotropha, but smaller and paler in ground colour than $C$. diakonoffi, with postmedial fascia clearly defined and curved, and termen arched, as opposed to the postmedial fascia ill-defined and only slightly arched distally and to straight and oblique termen in $C$. diakonoffi. The female genitalia of $C$. paradiakonoffi sp. n. (Figs III, 4 and 6) are similar to those of $C$. diakonoffi (Figs III, 5 and 7), but the bridge between the eighth abdominal segment and the sterigma is longer and strongly dentate, and the sterigma is longer and less enlarged with the first inner fold smaller and closer to the bridge.

DESCRIPTION (Fig. I, 8) - Wingspan $30 \mathrm{~mm}$. Labial palpi $4 \times$ longer than widest diameter of eye, brown with inner side creamy brown. Maxillary palpi well developed, brown with white tip. Antenna simple, brown with silvery brown costa. Frons rounded, slightly produced, creamy brown. Ocelli absent. Chaetosemata strongly reduced. Head creamy brown, with brown tuft around chaetosemata. Patagia brown, paler in middle. Tegulae brown. Thorax light brown. Forewing ground colour tawny with subdorsal dot dark brown; medial fascia very narrow, crossing straight almost all of dorsal area, then in vertical section strongly serrate; postmedial fascia serrate, gently outcurved at R5-M1; terminal line absent; with eight dark brown terminal dots; apex slightly acuminate; termen barely concave near apex and clearly convex in middle; fringes creamy brown; underside glossy light brown with interveins brown. Hindwings glossy white with concolorous fringes; underside glossy white suffused with yellow. Legs brown with welldeveloped first pairs of tibial spurs and minute second pairs of spurs.

Male unknown.

Female genitalia (Figs III, 4 and 6): Papillae anales elongated, moderately up-curved dorsally and slightly down curved ventrally. Apophyses posteriores slightly more than twice as long as apophyses anteriores, enlarged basally, then strongly narrowing. Apophyses anteriores subtriangular at base, slender. Abdominal segment VIII strongly developed, tubular, joined to sterigma by a strongly sclerotized and tridentate bridge. Ostium bursae sub-oval; sterigma strongly produced for 0.8 length of eighth abdominal segment, slightly bent inwards, moderately enlarging apically, folded in inner side basally and subapically. Ductus bursae three times as long as sterigma, moderately sclerotized basally, then wrinkled and distally scobinate. Ductus seminalis branching off anteriorly at one-third of ductus bursae. Corpus bursae suboval, shorter than ductus bursae, completely scobinate.

\section{ACKNOWLEDGMENTS}

I thank Dr A. Durante, the Museo di Storia naturale del Salento, the CENAREST (Centre National de la Recherche Scientifique et Technologique), the IRET (Institut de Recherche en Ecologie Tropicale), and the ANPN (Agence Nationale des Parcs Nationaux du Gabon) for permitting and organizing the research expedition to Ipassa in the Ivindo National Park. A particular word of thanks to the staff of BMNH, HNHM, MRAC and Dr A. Poltavsky (Rostov on Don) for the loan of material, to Dr A. Hausmann for the loan of material and for his help in DNA barcoding, and to Dr B. Landry (MHNG), for the loan of material, for reviewing the text, and for his valuable suggestions. I also owe a great deal of gratitude to Pier Luigi Scaramozzino, Dept. of Agriculture, Food \& Environment, University of Pisa, for his crucial help with the photographic work performed for this article. Finally I thank the reviewers of the manuscript for their valuable suggestions.

\section{REFERENCES}

BAssi G., 1999 - Notes on Pseudocatharylla Bleszynski, 1961 (Lepidoptera: Crambidae: Crambinae) with a description of new genera and new species. - Bollettino del Museo Regionale di Scienze Naturali Torino, 16 (1- 
2): $151-188$.

BAssi G., 2013 - Notes on some Old World Prionapterygini Landry, 1995 (Lepidoptera: Pyraloidea, Crambidae, Crambinae), with descriptions of new species. - Revue suisse de zoologie, Genève, 120 (1): 131-160.

BŁESZYŃSKI S., 1961 - Revision of the World species of the Family Crambidae (Lepidoptera). Part I. Genus Calamotropha Zell. - Acta Zoologica Cracoviensia, 6 (7): 137-272, pls 20-71.

BŁESZYŃSKI S., 1964 - Revision of the world species of the family Crambidae (Lepidoptera). Part 2. Genera: Pseudocatharylla Blesz., Classeya Blesz., Pseudoclasseya Btesz. and Argentochiloides Błesz. Acta Zoologica Cracoviensia, 9 (11): 683-760.

De Prins J., De Prins W., 2018 - Afromoths, online database of Afrotropical moth species (Lepidoptera). World Wide Web electronic publication (www.afromoths.net) [August 2018].

deWaArd J.R., IVAnova N.V., Hajibabaei M., Hebert P.D.N., 2008 - Assembling DNA barcodes: analytical protocols. In: Martin, C. (Ed.), Methods in molecular biology: environmental Genetic data. Humana Press, Totowa, NJ, pp. 275-293.

HAMPSON G.F., 1919a - Descriptions of new Pyralidae of the subfamilies Crambinae and Siginae. - Annals and Magazine of Natural History, including Zoology, Botany and Geology, London (ser. 9), 3: 275-292, 437-457, 533-547.

HAMPSON G.F., 1919b - Descriptions of new Pyralidae of the subfamilies Crambinae and Siginae. - Annals and
Magazine of Natural History, including Zoology, Botany and Geology, London (ser. 9), 4: 53-68, 137-154, 305326.

KLots A.B., 1970 - Lepidoptera. In: Tuxen SL (Ed.) Taxonomist's glossary of genitalia in insects. (Second revised and enlarged edition). - Munksgaard, Copenhagen, 115-130.

KRISTENSEN N.P., 2003 - Skeleton and muscles: adults. In: Kristensen NP (Ed.) Lepidoptera, moths and butterflies. Vol. 2. Morphology, physiology, and development. Handbook of Zoology IV (36). Walter de Gruyter, Berlin, New York, 39-131.

IVANOVA N.V., DEWAARD J.R., HEBERT P.D.N., 2006 - An inexpensive, automation-friendly protocol for recovering high-quality DNA. - Molecular Ecology Notes, 6: 998-1002.

MABILle P., 1900 - Lepidoptera nova malgassica et africana. - Annales de la Société Entomologique de France, Paris, 68: 723-753.

Nuss M., Landry B., Vegliante F., TränKner A., Mally R., Hayden J., Segerer A., Li H., Schouten R., Solis M., A., Trofimova T., Speidel W., 2003-2017 - Global Information System on Pyraloidea. Available from: www.pyraloidea.org. [August 2018].

RoBINSON G.S., 1976 - The preparation of slides of lepidoptera genitalia with special reference to the Microlepidoptera. - Entomologist's Gazette, 27: 127132.

SNELLEN P.C.T., 1872 - Bijdrage tot de Vlinder-fauna van Neder-Guinea, Zuidwestelijk gedeelte van Afrika. Tijdschrift voor Entomologie, 's Gravenhage, 15: 1-110. 